The University of Maine

\title{
DigitalCommons@UMaine
}

Marine Sciences Faculty Scholarship

School of Marine Sciences

$1-1-1980$

\section{Attitudes Towards Limited Entry Among Fin Fishermen in Northern New England}

James Acheson

University of Maine - Main, acheson@maine.edu

Follow this and additional works at: https://digitalcommons.library.umaine.edu/sms_facpub

Part of the Agricultural and Resource Economics Commons, $\underline{\text { Aquaculture and Fisheries }}$ Commons, and the Social and Cultural Anthropology Commons

\section{Repository Citation}

Acheson, James, "Attitudes Towards Limited Entry Among Fin Fishermen in Northern New England" (1980). Marine Sciences Faculty Scholarship. 17.

https://digitalcommons.library.umaine.edu/sms_facpub/17

This Article is brought to you for free and open access by DigitalCommons@UMaine. It has been accepted for inclusion in Marine Sciences Faculty Scholarship by an authorized administrator of DigitalCommons@UMaine. For more information, please contact um.library.technical.services@maine.edu. 


\title{
ATTITUDES TOWARDS LIMITED ENTRY AMONG FINFISHERMEN IN NORTHERN NEW ENGLAND
}

\author{
James M. Acheson
}

\begin{abstract}
Management of marine fisheries by "limited entry legislation" promises not only to protect the breeding stock and increase catches, but also to improve economic efficiency and increase returns to fishermen. It will also undoubtedly disrupt existing social and economic relationships. While no limited entry legislation is in effect in New England, fishermen know about the limited entry management option and have strong opinions that are certain to influence politicial support. Some of the 190 Maine and New Hampshire fishermen interviewed favor or oppose such legislation because their own "economic selfinterest" would be positively or negatively affected. Most, however, oppose or favor such legislation on "ideational grounds"-e.g., they favor "free enterprise." Quantitative data on attitudes towards limited entry and such factors as age of fisherman, primary species exploited, and versatility of fishing operation suggest that attitudes were more influenced by "self-interest" than many admitted overtly.
\end{abstract}

\section{THE PROMISE OF LIMITED ENTRY}

The past fifty years have seen a rapid decline in many of the world's most productive fisheries. For example, in the United States the Georges Bank haddock catch, once the mainstay of the New England fishery, declined from 120 million pounds in 1965 to a mere 11.7 million pounds in 1972 (Alexander 1972). Similar declines have been seen in the past few years in bluefin tuna, northern shrimp, the southern shrimp (penaeus species), Pacific sardine, northern lobster, dungeness crab, cod, Pacific halibut, surf clams, and many other species. Although natural environmental factors (e.g., water temperature) and industrial side effects (e.g., dams, pollution) have played a role in the decline of some species, the major problem in most cases is overfishing (Gulland 1974).

Fisheries economists have pointed out that overexploitation is not an unusual phenomenon, but is to be expected, given the fact that oceans are common property resources. Since oceans are owned by no one and can be exploited by anyone, no one has any interest in maintaining the resources. Why should one man cut his fishing effort to conserve? The fish he does not catch today will be caught by someone else tomorrow. Under these conditions, a fisherman is only being rational when he expands the amount of capital equipment he owns, and tries to catch all the fish he can as quickly as possible (Acheson 1975b; Wilson 1975).

THE AUTHOR: James $M$. Acheson is Associate Professor of Anthropology at the University of Maine. In 1974 and 1975, he worked for the National Marine Fisheries Service in Washington, D.C. Since 1977 he has been principal investigator of a large-scale project entitled "University of Rhode Island-University of Maine Study of the Social and Cultural Factors in Fisheries Management in New England Under Extended Jurisdiction," which was sponsored by the National Science Foundation. All of the data presented in this paper were collected as part of this project. He received his B.A. from Colby in 1970 and Ph.D. from the University of Rochester in 1962.
The result is what Hardin (1968) calls the "tragedy of the commons." Common property resources of all kindspublicly owned land, air, rivers, oceans-are subject to abuses and overexploitation that do not occur with privately owned resources. It is not only that common property resources are overexploited by a callous public; they are subjected to a kind of escalating abuse because those exploiting such resources are locked into a system in which it is only logical that they increase their exploitation without limit. As far as fisheries are concerned, the "tragedy" takes the form of overexploitation, depletion of fish stocks, inefficiency underutilization of capital, escalating costs of fish for the consumer, and where opportunity costs are high, the acceptance of low incomes (Hardin 1968: 1245-1246).

Usually attempts to regulate fisheries take the form of manipulating fishing seasons, fishing areas, and the type of fishing gear used. While such regulations may limit fishing mortality, economists have pointed out that they are probably relatively ineffective and certainly make fishing more inefficient (Pontecorvo and Vartdal 1967; Crutchfield and Pontecorvo 1969; De Wolf 1974). This, in turn, lowers returns to the fishermen and raises prices for the consumer.

Several economists have argued that a far better management system would involve limiting entry into the fishery either by a licensing system (Pontecorvo 1967; Christy 1973) or by taxation (Pontecorvo and Vartdal 1967). The advantage of such limited entry systems is that they promise to substantially reduce fishing effort while promoting economic systems. In general, many fisheries managers favor the introduction of limited entry systems. They expect that such schemes will become the cornerstone of management policy under the Fisheries Conservation and Management Act of 1976, which extends Federal jurisdiction over fisheries out to 200 miles.

Certainly such management systems appear very promising. If limited entry systems were adopted, fishing mortality would be decreased as fishing effort declines, and the catch or harvest of fish would increase as well. This can be seen in Figure 1, which demonstrates that any legislation reducing the existing level of fishing effort would have the effect of increasing fish catches - at least until maximum sustainable yield is reached. Moreover, efficiency of the boats remaining in the 


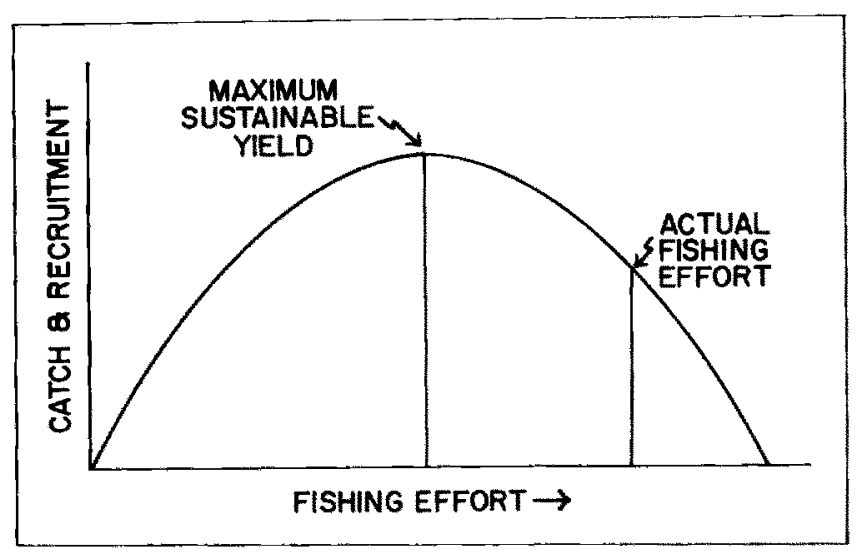

Figure 1. Relationship between fishing effort and catches.

fishery would be increased, since each boat would presumably be able to catch more fish per unit of effort. This would result in larger returns to owners of boats and higher wages to fishermen. The larger supplies of fish and the increase in efficiency should result in more fish being made available to the consumer at lower prices. Finally, the redundant capital and labor removed from the industry (that is, boats and fishermen no longer allowed to fish) would presumably be transferred to some other industry where they could be used more productively, and where returns would be higher. In short, limited entry promises to aid the fish, the fishermen, and the consumer alike.

Fishermen are clearly not convinced that limited entry holds forth the promise of the best of all possible worlds. When such systems are proposed, they feel very ambivalent about such plans or actively oppose them. Only a few limited entry laws have been passed-most notably in the salmon fisheries of British Columbia and Alaska - and they have received strong opposition. For example in 1974-75, there was a very serious attempt on the part of fishermen from Kodiak, Alaska, to overturn the Alaska law. In 1975, a bill to limit fishermen in the Maine lobster industry was soundly defeated in the state legislature because of opposition by certain industry groups.

Given the promise of limited entry legislation, and the fact that the Fisheries Conservation and Management Act of 1976 is written in ways that will certainly stimulate a series of limited entry proposals, it seems important to understand the factors influencing the political acceptability of such proposalsespecially the reasons fishermen oppose or advocate these management schemes. Fishermen are the interested players, and in the past they have demonstrated a marked capacity to effectively block attempts to manage fisheries, regardless of how badly regulation might be needed.

The reasons fishermen oppose limited entry legislation are not completely clear. However, several social scientists have noted that the major proponents of limited entry legislation are economists, who have focused on the economic and biological benefits and have overlooked the fact that such legislation will also cause disruption to existing social and economic systems (Andersen and Stiles 1973: 61-64; Stiles 1976:248 ff). These social scientists have hypothesized that opposition to limited entry stems from real or perceived deletorious social and economic effects of such legislation (Smith 1974). Our current study substantiates this hypothesis. However, our study demonstrates that the factors influencing the political support for limited entry legislation are complicated indeed. In the Maine groundfishery, fishermen both opposed and advocated limited entry legislation for a variety of reasons. More important, our data suggest that there is a substantial difference between the stated reasons concerning limited entry legislation and the underlying reasons influencing support or opposition.

\section{RESPONSES OF FISHERMEN CONCERNING LIMITED ENTRY PROPOSALS}

During 1977 and 1978 a team of social scientists from the University of Maine gathered a large amount of information from 190 captains of boats that fished primarily for finfish (mainly groundfish vessels, but some herring ones as well). The 190 interviews represent at least 65 percent of all finfishing boats in Maine and New Hampshire during 1977- 78. In addition to data on the captain, his boat, and fishing operations, a great deal of information was obtained on attitudes towards various possible ways to manage the fisheries of the region. Special emphasis was placed on gathering data on reactions toward limited entry.

The information on limited entry was obtained by openended interviews. We simply asked the fisherman involved if he "would approve or disapprove of limited entry legislation" for his section of the industry. Then we asked for an explanation. Fishermen knew a good deal about limited entry, had a good many ideas on the subject, and were not hesitant to communicate them. In great part, their interest and knowledge can be traced to the fact that a limited entry bill for the lobster industry - the largest fishery in Maine-had recently been proposed and defeated. There were also several articles on limited entry in the Maine Commercial Fishermen and other trade papers.

After the data were collected by the interview team, the results were run on the University of Maine IBM 370 computer.

In this paper, two different types of data resulting from this study will be presented: (1) the verbal statements of fishermen concerning the reasons they do or do not favor limited entry legislation-as we shall see, many of these responses are highly ideational and show a strong concern with broad philosophical positions with regard to governmental regulations and related issues - and (2) a set of quantitative data, linking attitudes towards limited entry to other social, technical, and economic factors. These latter data strongly suggest that fishermen are far more concerned with short run economic costs and benefits than some would care to admit.

Very few fishermen were neutral or ambivalent towards limited entry. The 190 fishermen questioned gave some 55 different answers on the topic. However, these responses clearly fell into six different classes, showing six different kinds of concerns. Two classes of responses showed a decided positive stance toward limited entry; four were negative. These classes of responses are summarized in Table 1.

Several people interviewed gave more than one of these answer types. Most fishermen, however, gave one answer or were clearly primarily interested in only one issue. Thus, we recorded in Table 1 only the primary response given by each respondent. A complete breakdown of secondary or tertiary answers is not presented since it added little to our understanding. Several comments need to be made on each of these responses.

Negative Response \#1. Men who gave this response were not against regulation per se. They wanted specific kinds of 


\begin{tabular}{|c|c|c|}
\hline Type of Response & Response of Fishermen & Number Responding \\
\hline Negative Response \#1 & $\begin{array}{l}\text { Limited Entry is not needed; other types of regulation should be } \\
\text { passed and are far more important. }\end{array}$ & 7 \\
\hline Negative Response \#2 & Natural economic or biological cycles will solve the problem. & 15 \\
\hline Negative Response \#3 & $\begin{array}{l}\text { I am against limited entry since it may prevent me or close kinsmen } \\
\text { from fishing. }\end{array}$ & 12 \\
\hline Negative Response \#4 & $\begin{array}{l}\text { The "Adam Smith" response: I am against limited entry because } \\
\text { this is supposed to be a free country; there are too many regula- } \\
\text { tions now. Free enterprise will handle the problems of the fisheries } \\
\text { better than the government. }\end{array}$ & 61 \\
\hline Positive Response \#1 & $\begin{array}{l}\text { I am for limited entry since there are too many boats, traps, nets, } \\
\text { and fishermen now. Something has to be done to ensure that some } \\
\text { fish will survive to breed. }\end{array}$ & 28 \\
\hline Positive Response \#2 & $\begin{array}{l}\text { I am for limited entry since it will reduce excess competition and } \\
\text { benefit me personally }\end{array}$ & 28 \\
\hline Ambivalent & & 4 \\
\hline \multirow[t]{2}{*}{ Missing Data } & & 38 \\
\hline & Total & 148 \\
\hline
\end{tabular}

regulations that they thought would benefit their section of the industry more than limited entry would. Several different types of regulations were mentioned. One draggerman wanted larger mesh regulations; two herring stop-seiners favored laws prohibiting purse seiners from operating close to shore; another draggerman favored laws limiting the size of boats; two other dragger fishermen favored a ban on gillnetting on the grounds that "lost gill nets kill a lot of fish."

Negative Response \#2. Men who gave this response are really making two different kinds of arguments. First, they are suggesting that levels of stocks and populations are strongly cyclical, and that predation by man is not one of the primary factors responsible for the great fluctuations in fish stocks observed. In the words of one fisherman: "Why have a limited entry system to save the fish? The amount of fish is going to go up and down as it always has. The number of boats in the fishery has nothing to do with fish stocks. Other things like water temperature and food supplies are far more important." Some biologists would agree, at least in part (Dean 1979). Most population dynamicists would not, arguing that recruitment into the fishery (i.e. numbers of marketable fish) is dependent on the number of eggs in the water, which in turn is a function of number of breeding-sized fish.

The second argument these men are making is that overfishing will be reduced by economic pressure. That is, as fish stocks fall, some people will be forced out of business, which of course, will automatically reduce fishing pressure. In time, as natural conditions change, these men argue, the fish stocks will increase again.

Negative Response \#3. Very few men who gave this response said openly that they personally feared being removed immediately from the industry. They were all aware that those proposing limited entry provisions have always made provisions to "grandfather in" all those men currently fishing. A few openly said that they thought limited entry would result in more competition, which might force them from the business at some time in the future.

Most of the men who gave this response were concerned with closing out "my sons" or other "young people." This concern reflects the fact that effective lineage ties in Maine communities are very strong, and a great deal of the meaning of life is tied up with living in a particular place with a wide set of kinsmen (Acheson and Lazarowitz 1980; Lazarowitz and Acheson 1980). Many men enter fishing not because they are committed to the industry per se, but because it is the only occupation they can enter that allows them to live near home. There is, of course, no sense living at home, if the people you want to be near are forced to live in Pittsburgh, Muncie, or San José.

It should be understood clearly that very few of these men assumed that their sons or kinsmen would be prohibited outright from entering fishing. Rather, they were concerned that the rules governing entry into the fishery under a limited entry scheme would somehow favor wealthy people or large corporations. Five or six of these respondents said (in almost the same words): "No one is going to say that a poor boy can't go fishing, but you know it will be the big companies that will get the licenses or permits." While only 12 men mentioned this as a primary reason for opposing limited entry a much larger number of men mentioned "relatives" or "inheritance of the business' in passing. It was something they clearly did not quite know how to talk about. Men in the United States do have trouble talking about how much their family means to them. However, we received the distinct impression that a limited entry bill that was framed in such a way that it would interfere with traditional transmission of family fishing businesses would be opposed severely by a far larger number of men than our sample alone would indicate.

Negative Response \#4. The most common response was what we came to call the "Adam Smith response." That is, people said they opposed limited entry because it would mean government intervention and an end of free enterprise. Free enterprise, in their view, was obviously a good thing; and government intervention was both bad and ineffective as a solution to the problems facing fisheries.

Frankly, we never imagined that large numbers of people would give this response when asked about limited entry. At first, we were very suspicious, and tended to probe deeply to get at the other real reasons for opposition to limited entry. A surprising number, when questioned, went into long spiels about the "government," liberally laced with much invective. It was very clear that most of these people really had a strong 
distaste for additional regulation, and did not believe that the government could solve the problems of fisheries (or very much else, for that matter). In this respect, these fishermen are joining the millions of Americans who have made California's tax-cutting Proposition 13 a potent political reality all across the nation.

Our probing, however, revealed two other deeper concerns. First, some 20 men who were concerned about "the government" were automatically assuming that the rules and regulations a government would pass would benefit large corporations or other wealthy interests. In this respect their responses were not much different from those who gave negative responses \#3.

The other concern was one that many people could hardly articulate clearly. Many kept talking about welfare, and about being protected by "big brother" government. They clearly did not like either. In the phraseology of two men, "Limited entry doesn't protect the fish; it protects fishermen."

Most of these stock phrases about government, we are convinced, reflect certain basic values and presuppositions - the most difficult subjects for the people of a culture to articulate. These answers reflect the fact that people in the fishing industry place great value on doing something useful, on earning their own way, and take pride in contributing to the food supply of the nation. Limited entry, in the view of many, threatened these basic values and their own sense of worth.

Positive Response \#1. Twenty-eight men favored limited entry because this legislation was necessary, in their view, to preserve fish stocks. None of them was happy at the thought of more government regulation, but they thought that some control on fishing effort was needed and that limited entry both would be effective and would cause the fewest problems. As one person phrased it, "There are just too many boats, men, and traps. More are coming all the time, and the gear is getting more efficient. If we are going to have any fish left to catch, some of these fishermen are going to have to earn their living in some other line of work. That's the truth." The mood of these respondents was somber. They clearly had misgivings about the viability of their industry and about limited entry.

Positive Response \#2. Some 25 people in the sample approved of limited entry legislation because they were sure it would help them personally in both the short and long run. Most of them assumed that since they were established in the business, they would be granted a license to continue fishing. They saw the benefits primarily in terms of decreased competition as potential new entrants were excluded from the fishery. Eight of them said they expected limited entry would bring gradual increase in fish stocks and catches. However, concern for the welfare of the fish stocks was a secondary importance.

\section{STRUCTURAL POSITION AND ATTITUDES TOWARD LIMITED ENTRY}

When asked about limited entry, a very high percentage of the respondents mentioned ideational issues (i.e., negative response \#4), and stressed their faith in free enterprise as a solution to the problems of overexploitation and their lack of faith in government regulation. Only those giving positive response \#2 and negative response \#3 mentioned their own economic self-interest. There is, however, a good deal of quantitative evidence that many, if not most, of the fishermen questioned are very concerned about the effect of limited entry legislation on their own economic position. This appears to be the case whether or not they admitted it openly.
There are significant correlations between attitudes toward limited entry and age, major species sought, and the versatility of a man's fishing operations, which indicate a great deal about social, economic, and technical factors underlying attitudes concerning management.

Table 2. Attitudes toward limited entry by age of fisherman.

\begin{tabular}{|c|c|c|c|}
\hline & Under 39 & 40 or over & Total \\
\hline $\begin{array}{l}\text { For limited entry }{ }^{a} \\
\text { Opposed to limited }\end{array}$ & 28 & 15 & 43 \\
\hline entry ${ }^{b}$ & 33 & 42 & 75 \\
\hline Total & 61 & 57 & 118 \\
\hline
\end{tabular}

Chi square $=4.007$

Degrees of freedom $=1$

Level of significance $=>0.05$

"Those listed as "for limited entry" gave either positive response number 1 or number 2 .

'Those listed as "opposed" gave one of the four negative responses listed in Table 1.

\section{AGE AND LIMITED ENTRY}

There is a very strong relationship between the age of the fisherman and his attitudes toward limited entry legislation (Table 2).

In Table 2, we see that a fair proportion of men under the age of 39 are "for" limited entry legislation, while a high proportion of men over the age of 40 oppose it. The reason for these responses is related to differential incentives. Young men stand to gain by such legislation; a high proportion of the older men do not. Since limited entry legislation will produce higher fish yields in an estimated five to thirty years, passage of such legislation will mean that older men will pick up the costs in terms of decreased catches, and so on now, and long after they are dead or retired the benefits will acrue to others. A good many fishermen are well aware of this situation, and will talk about it when pressed. One 74-year-old New Harbor fisherman expressed it as follows: 'I ain't going for nothin' of the likes (i.e., limited entry). Maybe it will bring in the fish by the year 2000 but I'll be long gone by then. I'm thinkin' of what I can catch from one year to the other."

These men, and others their age, were clearly assigning a high discount rate to future catches. It is obviously not in the best interest of such people to conserve fish now so that someone else can get higher yields in the future.

\section{LIMITED ENTRY AND PRIMARY TARGET SPECIES}

As can be seen in Table 3, fishermen in different kinds of fishing enterprises have very different attitudes towards limited entry. The results are significant at the 0.01 level, so that it is very unlikely that these results could have occurred by chance alone.

In general, the men whose primary species was lobster strongly favored "limited entry" legislation. Another study involving a much larger sample of lobster fishermen showed exactly the same thing (Acheson 1975a). There are two reasons. First, lobster fishing has become less profitable in recent years. Total catches have remained about the same for the 
Table 3. Attitudes towards limited entry by primary species sought. ${ }^{a}$

\begin{tabular}{lccccc}
\hline & Scallops & Lobster & Herring & Groundfish & Total \\
\hline $\begin{array}{l}\text { For limited entry } \\
\begin{array}{l}\text { Opposed to limited } \\
\text { entry }\end{array}\end{array}$ & 0 & 12 & 0 & 30 & 42 \\
\begin{tabular}{l} 
Total \\
\hline
\end{tabular} & 5 & 7 & 10 & 51 & 73 \\
\hline
\end{tabular}

Chi square $=6.9$

Degrees of freedom $=3$

Level of significance $=0.01$

aOur sample of 190 fishermen all fished for groundfish over some part of the annual cycle. Some had another species as their major target species, however.

"Those listed as "for limited entry" gave either positive response number 1 or 2 , as indicated in Table 1 .

'Those listed as opposed gave negative responses 1 to 4 .

past 10 years, while the amount of effort has increased enormously (Morrissey 1968: Table 20).

In addition, lobster fishermen have always limited their numbers by informal means. In order to go lobster fishing at all, one must not only have a license, but also gain entry into a "harbor gang." Once a person is admitted to such a "gang" or clique, he is permitted to go fishing only in the territory "owned" by that "gang" (Acheson 1972, 1975a, 1975b, 1979). Part-time fishermen, or others who are not members of the harbor gang, are usually heavily sanctioned by surreptitious destruction of their fishing gear. In short, lobstermen favor limited entry more than any other group primarily because they are fully aware that there are too many lobster fishermen, and because such legislation is congruent with existing norms prevailing in the industry.

A moderate proportion (37 percent) of the men who had groundfish as primary species also favored "limited entry." Most of these men noted openly that groundfishing was becoming crowded as larger numbers of lobster fishermen and others moved into this fishery. Many of them favored limited entry since it promised to reserve this fishery for those already

Table 4. Versatility of fishing operation and attitudes toward limited entry.

\begin{tabular}{lccr}
\hline & $\begin{array}{c}\text { Dependence on } \\
\text { single species }\end{array}$ & $\begin{array}{c}\text { Versatile fishing } \\
\text { operation }^{\mathrm{c}}\end{array}$ & Total $^{\text {To }}$ \\
\hline $\begin{array}{l}\text { Opposed to limited } \\
\quad \text { entry }^{\mathrm{a}}\end{array}$ & 24 & 50 & 74 \\
Favor limited entry $^{\mathrm{b}}$ & 5 & 38 & 43 \\
$\quad$ Total & & & 117 \\
\hline
\end{tabular}

Chi square $=5.24$

Degrees of freedom $=1$

Level of significance $=0.02$

"Men were classified as "opposed" to limited entry if they gave one of the four negative comments listed in Table 1.

"They were classified as "favoring" limited entry if they gave either positive response 1 or 2

'Men were classifled as having versatile fishing operations if they did one or more of the following: (1) make a major change in species sought over the year, (2) make a major change in fishing gear once in the annual cycle, (3) expect to buy a boat at least eight feet larger than their present boat in the near future, (4) expect to enter a more versatile type of fishing in the near future, (5) anticipate a major change in species mix exploited in the near future, (6) anticlpate a major change in vessel or gear in the near future. established in it. However, some 62.9 percent of those who had groundfish as their primary species did not favor limited entry. Most of these objected to this kind of legislation on ideational grounds (negative response \#4), and gave long lectures on the values of free enterprise, and so on.

All of the men who had herring and scallops as major species "opposed" limited entry legislation. While the numbers involved are too small for statistical reliability, it should be noted that several of these men admitted openly that they had been "doing very well" in the past two or three years. They did not want any legislation passed (i.e. limited entry) that would change or modify a very profitable fishery. Most of these scallopers and herring fishermen said they opposed limited entry for ideational reasons (negative response \#4). However, their own economic self-interest was only barely under the surface.

\section{VERSATILITY OF FISHING OPERATIONS AND ATTITUDES TOWARDS LIMITED ENTRY}

A few fishermen in recent public hearings concerning fisheries management legislation have openly opposed limited entry on the grounds that they were involved in several different fisheries over the annual cycle and were afraid that limited entry legislation would prevent them from exploiting the vaniety of species needed to make a living fishing. For example, one fisherman phrased the issue in this way: "To keep the wolf away from the door we have to switch from scallops to finfish to lobsters" (Maine Commercial Fisheries 1979:1). A good many other fishermen stated during the course of being interviewed that they were planning to buy more versatile boats and fishing gear, since they were afraid of being "closed out" of the fishery they were in by Federal legislation (Acheson 1980).

With these kinds of comments in mind, we originally hypothesized that men who depended on one species would favor limited entry, since this would reserve this species for them exclusively. Correspondingly, those who exploited multiple species over the year, or who planned to have versatile operations, would oppose such legislation, because limited entry would likely restrict the range of species open to them.

The data demonstrate that there is a strong connection between versatility of fishing operations and attitudes towards limited entry. They also show that our original hypotheses were absolutely wrong (see Table 4). 
From these figures it is apparent that a very high proportion (82 percent) of those who are dependent on single species are opposed to limited entry legislation, while a moderate percentage (43 percent) of those with versatile fishing operations favored such legislation. The Chi Square figures are significant at the 0.02 level, so that these results are very unlikely to have happened by chance.

A check through our original interview forms and subsequent calls to some of the fishermen interviewed strongly suggest that men dependent on a single species oppose limited entry because they are afraid such legislation would close them out of the fishery on which they are completely dependent. They are aware that such legislation might benefit "the fish in the long run" as one man phrased it, but they are concerned with making a living in the short run.

Over 50 percent of those with "versatile" fishing operations also oppose limited entry-mainly on ideational grounds. More of them favor it, however, than do the "single species" fishermen. Our information suggests that these respondents believe it will benefit either them personally or the fish stocks. In addition, they are not so fearful of limited entry as those with less versatile operations. After all, they have the capability of fishing for several species, so that limited entry would merely mean a change to another species-probably a species the fisherman is currently exploiting. We suspect that a lot of the men listed as "versatile fishermen" agree with one Portsmouth, N.H., respondent when he said: "The secret of success in this business is to be able to do everything: gillnet, drag, purse seine, scallop. The government may have to close off some fisheries some of the time; but they can't close them all off. People gotta eat, you know."

\section{SUMMARY}

The results of this study indicate that Maine and New Hampshire fishermen feel very ambivalent about limited entry. On the whole, support for such legislation would be greatest among lobstermen and groundfishermen; less among scallopers and herning fishermen. Younger men who fish or plan to fish for multiple species would support such legislation more than older men who are dependent on single species fisheries. Support will undoubtedly be linked to the ways in which specific legislation is framed. It will be greatest if limited entry bills minimize the day-to-day influence of governing agencies in fisheries, do not interfere with transmission of businesses from senior kinsmen to junior kinsmen, and give no special favors to large corporations that threaten a "corporate takeover" of the fisheries.

This is not to suggest that fishermen are solely concerned with short-run benefits and costs. There were two aspects of fishermen's attitudes towards limited entry that deserve significant mention in this regard.

First, there were a large number of men interested in longrun effects of limited entry schemes. This shows up in overt concern for the well-being of fish stocks (positive response \#1 and negative response \#1); the fact that many young men favored limited entry even though they are fully aware that the benefits will show up far in the future if at all; and in the questions fishermen have about the government's being able to positively affect fish stocks through legislation. A concern with the long-term situation is also revealed in the concern that limited entry regulations might be subtly rigged so that, sometime in the far future, the fisheries would "belong" to big corporations. These respondents were clearly not merely thinking of just making money at the expense of the fish stocks in the next month or next year.

Second, an overwhelming number of the fishermen interviewed were not just interested in limited entry as it affected their industry, but in any increase in governmental regulation. When we asked about limited entry legislation, we expected pointed and specific commentary on fisheries management. All too often, we received long treatises revealing a deepseated concern with trends in the Federal Government. Several respondents specifically mentioned Watergate and Koreagate. They were bothered by what they saw as Federal waste, the self-serving bureaucracy, and what recently has been termed as "Corporate Welfare." There were bothered by the so-called lack of leadership and the inability of politicians to propose creative solutions to pressing problems. They also are people who want to control their own lives, make their own decisions, and do something they consider useful in their own way.

Our experiences left us with the strong impression that the political support that limited entry legislation will receive lat least in Maine and New Hampshire) is currently tied up with attitudes and situations that go far beyond fish.

\section{LITERATURE CITED}

Acheson, J. M. 1972. Territones of the lobstermen. Nat. Hist. 81(4):60-69. 1975a. Fisheries management and social context. Trans. Am. Fish. Soc. $104: 653-668$

1975b. The lobster fiefs: Economic and ecological effects of territoriality in the Maine lobster industry. Hum. Ecol. $3\{3\}: 130-207$.

1977. Technical skills and fishing rights in the Maine lobster industry. Pages $169-189$ in Robert Merrìl and Heather Lechtman, eds. Material culture: Style, organization and dynamics of technology. West Publishing Co.

1979. Variations in inshore fishing rights in Maine lobstering communities.

Pages $000-000$ in Raoul Andersen, ed. Northern Atlantic maritime Europeans. Morton The Hague.

1980. Patterns of gear changes in the northern New England fishing industry. Pages $451-499$ in Final Report to National Science Foundation, Vol. 2. NSF Grant AER $77-06018$.

Acheson, J. M., A. W. Aches on, J. Bort, and J. Lello. 1980. The fishing ports of Maine and New Hampshire. In Final Report to National Science Foundation, Vol. 1.

Ackeson, J. M., and T. Lazarowtiz. 1980. Using the family jewels: The family estate in coastal Maine. In Final Report to National Science Foundation, Vol. 2.

Alexander, T. 1973. American fishermen are missing the boat. Fortune 88(3): $192-196$

Andersen, R., and G. Stiles. 1973. Resource management in Newfoundland fishing. In Peter Fricke, ed. Seafarer and community. Croo, London

Christy, T. 1973. Fishermen quotas: A tentative suggestion for domestic marlagement. Occas. Pap. 19. Law of the Sea Institute, Univ. Rhode Island, Kingston.

Crutchfield, J., and G. Pontecorvo. 1969. The Pacific salmon fisheries. Johns Hopkins Press, Baltimore, Maryland.

Dean, D. 1979. Personal communication.

DeWolf, G. 1974. The lobster fishery of the Mantime Provinces: Economic effects of regulations. Fish Res. Board Can. Bull. 187

Gulland, J. A. 1974. The management of marine fisheries. Univ. Washington Press, Seattle. Hardin, G. 1968. The tragedy of the commons. Science 162:1243-1248.

Huq, A. M., and H. Hasey. 1973. Socio-economic impact of changes in the harvesting labor force in the Maine lobster fishery. File ms. No. 142. Nat. Mar. Fish. Serv., Econ. Res. Div., Washington, D.C. $142 \mathrm{pp}$.

Lazarowtiz, T., and J. M. Acheson. 1980. Pruning the family tree: Kinship and community in coastal Maine. In Final Report to National Science Foundation, Vol. 2.

Maine Commercial Fisheries. 1979. Limited entry-Doubts. Maine Comm. Fish. 6(8):1.

Morrissey. T. 1968. American lobster fishery management plan. (A draft, 1968.) Lobster Sub Board of the Northeast Maine Fisheries Service.

Pontecorvo, G. 1967. Optimization and taxation in an open access resource: The fishery. Pages 157-167 in M. Gaffney, ed. Extractive resources and taxation. Univ. Wisconsin Press, Madison.

Pontecorvo. G., and K. Vartdal. Jr. 1967. Optimizing resource use: The Norwegian winter herring fishery. Statskonomisk Tidsskrift 2:65-87.

Public Law 94-265. Fishery conservation and management act of 1976. 90 Stat. $331-361$.

Smith, C. 1974. Fishing success in a regulated commons. Ocean Develop. and Int. Law J. 1(4):369-381.

Stiles, G. 1967. The small maritime community and its resource management problems: A Newfoundland example. Pages $000-000$ in Douglas Johnson, ed. Marine policy and the coastal community. Croom Helm, London.

Wilson, J. A. 1975. The tragedy of the commons: A test. In J. Baten and G. Hardin, eds. Managing the commons. Freeman. San Francisco. 